\title{
Defunding the ramparts: $A$ home remade
}

\author{
Michael J. DeValve*
}

Institutional theory reveals for us what is broken in policing, but, beyond that, it highlights why it is so broken and where work must be focused. A justice founded on love is more than just possible, but the work to be done is considerable and frightening. It is, however, wildly fruitful and also blindingly beautiful.

Institutional theory is useful for understanding policing, certainly, but primarily in a revelatory sense; in the current crisis of police legitimacy (see Vitale, 2017), institutional theory rends the veil and sharpens the focus on what, precisely, is so broken in policing. It also reveals that what is broken has been so for quite some time. What is more, institutional theory places responsibility for police brokenness squarely on the shoulders of you and me. Through boundary-spanning interactions, organizations like the police ingest and metabolize myths because doing so makes them more viable long-term as organizations, not because those myths serve the broader organizational purpose. Those myths are a result of our understandings - and misunderstandings - about the police and about justice writ large. Organizations do what they do so as to keep existing, not necessarily to succeed in their mission. Clearly, then, the onus is on the policed to understand well what precisely the police can do, what they should do, what they are asked to do, and most of all, what justice means in fullness.

Decoupling, or the gap between stated purpose and actual action, is particularly evident in policing, where it is also particularly toxic because of the nature of the police role. Proactive, direct enforcement strategies offer marginal deliverables regarding safety, and likely victimize segments of the community, yet other segments of the same community urge the police to use those same strategies in the interest of "order" or "community safety."

The competing and colliding myths that disrupt the environment of the police institution are a function of cocreated discourses related to police purpose, police action, and the meaning of justice. These myths even embody the deep decoupling itself that is emblematic of the institution.

Crucially, these myths, tugging the police in various directions at different strata, are perpetuated according to the degree to which they resonate with individuals. What resonates, of course, is a function of the topography of need in each of us and in terms of the wider human community, and it is for this reason that we do well to contemplate together the topographies of that need in the wider human community and the ways we can organize to address them.

The range of guiding myths for policing is not only bedecked with false and misleading ideas, it is deeply valanced in at least two wildly different vectors. On the one hand, there is a vector that urges a wisdom, a softening of the shape of boundary-spanning contacts (e.g., DeValve \& Quinn 2010). This vector is not nearly as prolific or as influential as the second one, which urges a honing of the edge (e.g., Crank, 2015) through militarization, not only of equipment, but of personnel and of the very spirit of the agency (e.g., Kraska, 2001).

The might of myths, as indicated earlier, is a function of their appeal, which is in turn a function of their analgesic capacity. A very brief consideration of the shoreline of American suffering in the body of certain addictions is warranted.

\begin{abstract}
Addictions
We have an opiate problem in the United States, in addition to the one everyone has been discussing of late. The failure of the police institution is predominantly historic rather than merely recent; in this moment we are seeing revealed the collapse of meaningfulness in policing that occurred well in the past. Of course, some officers and even some agencies serve with dignity and integrity, but that dignity and integrity have been more the exception than the rule, and this for quite some time. This yawning chasm between perceived (or desired) and actual policing service in America frames a series of soothing fairy tales for us, appealing for their analgesic effects. As a result, we have tended to become addicted to these soothing stories. The fairy tales are themselves instructive precisely because they are so effective, telling us almost directly about the nature of our suffering. Here we will consider the fairy tales to which we have become addicted so as to learn about the pain they mask.
\end{abstract}

\section{Certainty}

First among the fairy tales is the craving for certainty. We want to know what is going to happen, we want to be sure everything will be okay. Entire industries are built on the idea of providing insurance against the unforeseen, over which we have no control. We stuff cash in mattresses and arm ourselves against intruders because we fear what could

Correspondence to: Michael J. DeValve, PhD, Assistant Professor, Department of Criminal Justice, Bridgewater State University, Bridgewater, MA O2325.
E-mail: mdevalve@bridgew.edu

To cite: DeValve, J. M. (2020). Defunding the ramparts: A home remade. Journal of Community Safety and Well-Being, 5(4), 168-170. https://doi.org/10.35502/jcswb.161 (C) Author(s) 2020. Open Access. This work is distributed under the Creative Commons BY-NC-ND license. For commercial re-use, please contact sales@sgpublishing.ca. gPUBLISHING Published by SG Publishing Inc. CSRA Official publication of the Community Safety Knowledge Alliance. 
happen instead of living our lives in celebration of them happening (e.g., Jones, 2011).

As I have said elsewhere (e.g., DeValve, 2020), we humans tend to struggle for a toehold as we bob like desperate corks in the surf. We long for certitude, even though uncertainty is endemic to the human experience. Legitimacy, coercion, fairness, and the rest are rooted in this clawing after certainty. The search for best practices, fully illustrative of institutional theory's fecundity, is itself a bad practice. The pursuit of certitude is in actuality laziness; this point deserves emphasis: it is far easier to build a repository of empirically derived tests of marginally effective justice practices than it is simply to connect, bodily, humanly, with what is actually broken.

The notion of police effectiveness vis-à-vis crime is deeply held-even by many, including police executives (e.g., Haberman, 2016), who likely know better. It is more than merely believing their own organizational hype; there seems to be a strange bifurcated sense of efficacy: police executives work hard to do and outwardly praise activity that has only marginal efficacy, and yet they seem to live with an inherent awareness, not only that these efforts are marginally impactful, but that they must believe in them as being the best chance of serving the stated organizational mission. Moreover, this internalized bifurcation of efficacy is undiscussable, and its undiscussability is undiscussable (e.g., Argyris, 1980). In a sea of uncertainty, police executives cling to what they have and insist on its relevance and efficacy despite evidence. One is reminded of William Golding's (1956) Christopher Martin, clinging to a rock in the tempest-tossed sea, clinging ever more tightly as fear mounted, clinging to what had already been lost.

\section{Authority and the Telos}

Related to our need to mainline certainty is the belief in authority as meaningful. Power-over relations provide some sense of being ruddered towards something. Power-over is as fulfilling as heroin is nutritious, however; power-with relations are far more sustainable and nutriment-rich (e.g., DeValve, 2016).

There is a near-paradox that, to my knowledge, remains unacknowledged in institutional theory discourse (although DiMaggio \& Powell (1983) come within a hair's breadth of the point in a footnote). If environmental forces are more potent for ensuring the long-term viability of an organization than are "rational" (or semi-rational, e.g., Copes \& Vieraitis, 2009; March \& Simon, 1958), efficiency-optimized structures and actions, is it not the case, then, that prioritizing environmental myths over efficiency is inherently reasoned and goal-directed? While legitimacy may not be an efficient concern regarding outcomes and impacts, it is an effective one, but, revealingly, only when it is authentically pursued as such. Goal-directed activity naturally presupposed the continued existence of the organization, therefore organizational viability is at least as important as efficiency. What is more, it is inherently goal-directed for a police agency which authentically serves the mission of community well-being to orient itself in an unqualified way to love as I have defined it: "the artlike, individualized, unconditional, aware and endless praxis whereby a human or organization mindfully, assertively and continuously labors for the actualization of another human being as an end in herself without thought of return, without reliance upon authority, without fear, or the possibility of cessation" (DeValve, 2015, p. 103).
Recently I wrote about how we respond collectively to mass violence, like Stephen Paddock's shooting in Las Vegas (DeValve, 2020). Two tendencies are at work here. First, there is a tendency to shake our fists at God after such an atrocity; we seek an accounting of why bad things happen if God is both good and mighty. This, of course, is the contemplation of theodicy (e.g., Metz, 1998; Tillich, 1963), which has a long and storied history. The second tendency for many contemporary humans is to understand the human world and its meaning in the form of a narrative: all of this suffering must make sense, and all will be revealed. That there is no why, no grander narrative (aside from the one we ourselves weave) is deeply unsettling for many; if there is no Grand Purpose, then there is no Grand Narrative, and logically there is no Grand Author. In actuality, though, the craving for authority, for a Grand Narrator, misses the vital point that we ourselves are coauthors in all things; we make meaning, we tell the story, we choose the ending.

\section{Wiley Coyote and Moenia Populi}

And speaking of narratives, we all know that Wiley Coyote can't ever be allowed to succeed, his contraptions and his unquestioned super genius status notwithstanding. We want the police to legitimate themselves, and yet we want legitimacy (again, which are two often very different things). We cheer when evil Hans Gruber gets what's coming, and when John McLean gets the girl in the end. We want the police to kick ass, just not our own asses.

Elsewhere (DeValve, 2016), I talked about what I call the Wiley Coyote Problem: we insist that the Good Guys win, and place institutional pressure on the police to make sure that happens. How is it that we're surprised, then, when the police do win, but the "Bad Guy" was an unarmed and nonviolent father of three? We crave ramparts against the forces of evil, something we might call "the people's ramparts," or "moenia populi." The problem with this craving is that warlike myths simply don't serve, and moenia populi pivots almost imperceptibly, becoming moenia contra populi without warning.

\section{What ls to Be Done about the Police?}

First, it should be manifestly evident at this point that the police, as institutional agents of justice, serve justice as it is understood by the community. When the community understands justice only dimly if at all, it stands to reason that the police will follow suit, regardless of other, even functional constraints. Institutional theory seems to make clear that even if the police did indeed have effective goal-directed strategies for crime interdiction, they would still be compelled to do the things demanded by the community. If we are outraged by police violence, the place for us to turn must be to ourselves. If it is the case that our organizations reflect our demands, as institutional theory posits, then it is a categorical imperative that we make demands of those organizations that prioritize love above all things.

Second, our concerns about certainty cannot override our willingness to understand deeply the nature of the suffering confronted by public service organizations. We must learn that squeezing tightly those things that we treasure only assures their demise. We must give up our search for certainty and learn to love the surf. The secret, though, is that when we relinquish our craving for certitude and learn to revel in 
the confluence of the tide, we find within the very stillness and solidity we sought without.

Third, we must practice viewing all suffering with eyes of compassion and loving kindness. All suffering is caused by suffering, and that includes racism, greed, and the addictions to which I have pointed here. We must begin to dialogue about what hurts, and we must find the courage to listen and be fully present as individuals and as a community for that dialogue. Loving kindness is "smriti," Sanskrit for "that which can be remembered." There are multiple ways to remember, to rediscover nascent voices within ourselves, and many of them are rooted in some form of contemplative practice. There is a need, though, in this moment in American history, for a more formal and public remembering for the sake of the transformation of past harm into future healing. Truth and reconciliation efforts are needed in America; soon, hopefully, we will be sufficiently mature to take up the task.

Fourth, we should not see the choice of how to act as a zero-sum game; highest wisdom at an individual level will sort out the collective problems in time, but we do not have the luxury of waiting for the Buddha-nature of every human to come to full flower before we act. Rather, we should see the individual work and the collective work as collateral and cross-fertilizing avenues of progress towards a loving justice.

Finally, we must end the American Cult of the Self. The confrontation of ugliness (i.e., suffering) is endemic to human existence, and that ugliness, that suffering, is daily fare for police. That ugliness leads to an unresolved walking desperation, which resolves eventually into either compassion or hate. The inevitable choice to live in compassion or be consumed by hate often hinges on the understanding of the self. If the self is seen as sovereign, the tendency is to cling to it in unwholesome ways. This clinging results in what colleagues and I have referred to as either benign or antagonistic selfism (DeValve, Garland, \& Wright, 2018). If, however, a nondual sense of self is operable, the confrontation with wretchedness results in compassion, and power-over control (e.g., DeValve, 2017) no longer makes practical sense. That movement towards enlightened self through the sovereign self and to a wiser nondual self is a path, and crucially it is a path that cannot be walked at the tip of a spear or for some incentive (Tagore, 1913/2017).

It all comes down to choice: we can choose the easy road and cling to rusted institutions that failed to deliver on promises long ago even though they continue to give credence to those promises, or we can do the hard work of love and connect in granular and intimate ways to assure real justice arises like flowers for every single member of the human family.
CONFLICT OF INTEREST DISCLOSURES

The author has no conflicts of interest to declare.

\section{AUTHOR AFFILIATIONS}

* Department of Criminal Justice, Bridgewater State University, Bridgewater, MA.

\section{REFERENCES}

Argyris, C. (1980). Making the undiscussable and its undiscussability discussable. Public Administration Review, 40(3), 205-213.

Copes, H., \& Vieraitis, L. (2009). Bounded rationality of identity thieves: Using offender-based research to inform policy. Criminology \& Public Policy, 8(2), 237-262.

Crank, J. (2015). Understanding police culture, 2nd ed. Routledge.

DeValve, M. (2015). A different justice: Love and the future of criminal justice practice in America. Carolina Academic Press.

DeValve, M. (2016). O for a muse of fire: Rebellion as sacrament. Critical Criminology, 25, 87-102.

DeValve, M. (2017). Love/power. Critical Criminology, 25, 375-391.

DeValve, M. (2020). Reconsidering the response to mass violence: Choice, meaning and human truth. Journal of Theoretical and Philosophical Criminology, 12, 80-97.

DeValve, M., Garland, T., \& Wright, B. (2018). A unified theory of justice and crime: Justice that love gives. Lexington/Rowman \& Littlefield.

DeValve, M., \& Quinn, E. (2010). Practical poetry: Thich Nhat Hanh and the cultivation of a problem-oriented officer. Contemporary Justice Review, 13(2), 191-205

DiMaggio, P. J., \& Powell, W. W. (1983). The iron cage revisited: Institutional isomorphism and collective rationality in organizational fields. American Sociological Review, 48(2), 147-160.

Golding, W. (1956). Pincher Martin. Capricorn.

Haberman, C. (2016). A view inside the "black box" of hotspot policing from a sample of police commanders. Police Quarterly, 19(4), 488-517.

Jones, D. (2011). The art of uncertainty: How to live in the mystery of life and love it. Tarcher/Penguin

Kraska, P. (2001). Militarizing the American criminal justice system: The changing roles of armed forces and police. Northeastern University Press.

March, J., \& Simon, H. (1958). Organizations. New York: Wiley.

Metz, J. (1998). A passion for God: The mystical-political dimension of Christianity. (Ashley, M., Trans.). Mahwah, NJ: Paulist.

Tagore, R. (1913/2017). Sadhana. In Tagore, R., The complete works of Rabindranath Tagore: All short stories, poetry, novels, plays \& essays. (Kindle Edition). New Delhi: General Press.

Tillich, P. (1963). Systematic theology. University of Chicago Press.

Vitale, A. (2017). The end of policing. Verso. 